Marquette University

e-Publications@Marquette

College of Communication Faculty Research and

Publications

Communication, College of

$8-1-2006$

Who 's Watching Us at Work? Toward a Structural-Perceptual Model of Electronic Monitoring and Surveillance in Organizations

Scott C. D'Urso

Marquette University, scott.durso@marquette.edu

Accepted version. Communication Theory, Vol. 13, No. 3 (August 2006): 281-303. DOI. The definitive version is available at www3.interscience.wiley.com. (C) 2006 Wiley-Blackwell. Used with permission. 


\title{
Who's Watching Us at Work? Toward a Structural-Perceptual Model of Electronic Monitoring and Surveillance in Organizations
}

\author{
Scott C. D'Urso \\ Marquette University \\ Milwaukee, WI
}

\begin{abstract}
:
Nearly $80 \%$ of organizations now employ some form of employee surveillance. This significant level of use infers a salient need for additional theory and research into the effects of monitoring and surveillance. Accordingly, this essay examines the panoptic effects of electronic monitoring and surveillance (EM/S) of social communication in the workplace, and the underlying structural and perceptual elements that lead to these effects. It also provides future scholarly perspectives for studying EM/S and privacy in the organization from the vantage point of contemporary communication technologies, such as the telephone, voicemail, e-mail, and instant messaging, utilized for organizational communication. Finally, four propositions are presented in conjunction with a new communication-based model of EM/S, providing a framework incorporating three key components of the panoptic effect: (a) communication technology use, (b) organizational factors, and (c) organizational policies for EM/S.
\end{abstract}


In the post-September 11th world, issues of privacy, monitoring and surveillance are now at the forefront of concerns among the citizens of the United States. With the implementation of the USA PATRIOT Act in October 2003, many U.S. citizens and civil liberties organizations are concerned about the effects this law is having on the general population, in addition to the terrorist organizations it is intended to thwart. This act, originally signed by President Bush only a few weeks after the September 11th tragedy, greatly increases the government's ability to conduct surveillance by expanding its powers under several statutes, including the Federal Wiretap Act and the Electronic Communications Privacy Act (ECPA). The government, now that many of the procedural hurdles are gone (such as the need to show cause or obtain warrants), has, arguably, unprecedented authority to monitor and collect information. This power is seen most clearly, perhaps, in the recent revelations by the federal government that in certain circumstances U.S. citizens have been targets, sans warrant, of federal surveillance. Although this type of government activity seems to go against rights guaranteed to the citizens of this nation, a cursory examination of the U.S. Constitution reveals no explicit "right to privacy," ${ }^{1}$ despite the fact that this basic right is often thought to apply to nearly every aspect of civic life.

The USA PATRIOT Act and other legislation brings more attention to the broader and more common practice of surveillance of employees by nearly $80 \%$ of organizations (American Management Association, 2001) and to the apparent lack of concern regarding this longstanding practice. The current climate supporting surveillance is a potential signal to many organizations that surveillance of employees continues to be tolerated at unprecedented levels. Moreover, in the workplace, though employees may assert privacy protection for their own personal effects, they cannot claim similar protection for activities conducted through the use of the employer's papers or effects (Cozzetto \& Pedeliski, 1997). Although current law protects individuals from surveillance of personal communication, exceptions provide work organizations many loopholes that allow them to monitor their employees, sometimes with little or no notice.

This essay seeks to provide additional insight that expands theoretical understanding and knowledge of a vital area of communication research. The ever-increasing relationship between 
workplace surveillance and key organizational outcomes has yet to be adequately explained by previous theory and research. While the issues associated with privacy, monitoring, and surveillance ${ }^{2}$ are broad in scope, the focus of this essay centers on electronic monitoring and surveillance (EM/S) as it pertains to the work environment, and on social (non-task) communication in particular. Specifically, Botan's (1996) work on panoptic effects, and the panoptic effect model in particular, provides this essay's basic framework. Moreover, in light of contemporary events, a new and expanded panoptic effects model is offered, focusing on the impact of communication technology, organizational factors, and policy.

\section{Review of EM/S Literature}

Several rationales can be offered to underscore EM/S as a key facet of organizational communication research, especially for understanding today's organizations. First, as Botan (1996) noted, the workplace is the center of the information society. Second, surveillance in the workplace has continued to increase at dramatic levels, especially with Internet-based communication. Third, the presence of, or perceived presence of surveillance has the potential to have a significant impact on communication in general. Employing the basic sender-message- channel-receiver model of communication reveals that EM/S can affect each of those elements of communication by influencing the message a sender chooses to send or not send, the content of a message, the channel selected to deliver the message, and/or how the receiver chooses to receive and comprehend the message. Finally, as new communication technologies enter the workplace, more specific laws and regulations are needed to clarify the rights of both the employee and employer (Botan, 1996). The following section will discuss the state of EM/S in the workplace, focusing on examples, prevalence, and rapid growth of EM/S. Next, a rationale for modeling $\mathrm{EM} / \mathrm{S}$ is presented, which examines the justifications for its use and the effects that result from this use. Finally, a review of the theoretical contributions in the EM/S field will be offered paying special attention the work of Botan (1996) and the electronic panopticon. 


\section{The State of Electronic Monitoring and Surveillance in the Workplace}

Technology plays a large role in workplace observations. Nebeker and Tatum (1993) define electronic monitoring as "the use of electronic instruments or devices such as radio, video and computer systems to collect, store, analyze, and report individual or group actions or performance" (p. 509). This type of supervision can be classified as monitoring in general. Yet, if such monitoring were being done to uncover specific wrongdoing, then it is classified as surveillance. Looking at communication technology in particular, EM/S represents one of the most intriguing aspects of the general monitoring and surveillance field. Beyond measuring general progress or efficiency, this form often seeks to reduce excess utilization of company equipment, time, and resources for purposes other than the assigned tasks of the job.

In addition to looking at how EM/S is accomplished, analyzing what is being monitored yields some surprising results. Seventy-eight percent of major U.S. firms conduct surveillance on their employees; half monitored phone calls, either by recording them $(42.2 \%)$ or actually listening in on the calls $(11.9 \%$ ) (American Management Association, 2001). Over one third of employees who responded to a recent survey on workplace surveillance (Coopman, Watkins Allen, \& Hart, 2003) (most of whom held non-management positions - 85\%) and who, overall, represent a wide cross-section of organization size and types), reported that their organizations tracked employee visits to websites, and an additional 31\% reported not knowing if their website visits were tracked. Additionally, $23 \%$ of the respondents reported that their employers looked at the material on their computers, whereas $20 \%$ indicated that their e-mail messages were being read. A large number of the respondents were unsure of their company's surveillance policy for website tracking (40\%) and e-mail monitoring (33\%). While some of these figures are significant on their own, when examined as part of a larger trend, they are even more startling.

During the past two decades, the workplace is witnessing a steady increase in communication technology use and surveillance (Botan, 1996; Vorvoreanu \& Botan, 2000). The American Management

Communication Theory, Vol. 16, No. 3 (August 2006): pg. 281-303. DOI. This article is (C Wiley and permission has been granted for this version to appear in e-Publications@Marquette. Wiley does not grant permission for this article to be further copied/distributed or hosted elsewhere without the express permission from Wiley. 
Association (AMA) Electronic Monitoring and Surveillance Survey (2005) found that $55 \%$ of surveyed U.S. companies retain and review e-mail messages (as compared to $47 \%$ in 2001), $25 \%$ have terminated employees for e-mail policy infractions, and $84 \%$ reported that their organization has written policies concerning e-mail (up from $75 \%$ in 2003), but not all employees receive training on these policies. In an earlier AMA study (2003), they found that approximately one third of these organizations have formalized e-mail retention and detention policies in place. The average worker spends nearly a quarter of the workday on e- mail. Ninety percent of those surveyed admitted that some of their e-mail - usually less than $10 \%$ - is personal in nature, and $13 \%$ of those surveyed reported not knowing if their e-mail was being monitored. According to the AMA report, most employers do give employees prior notice of monitoring activity at the workplace and typically employ it for random checks or in the situation where there is a suspected threat. These statistics are even more noteworthy when you consider the prevalence of use of these technologies.

In September of 2001, 72.3 million individuals surveyed reported using a computer at work, comprising over half the total employed U.S. workforce (U.S. Census Bureau, 2001). In addition, $40 \%$ of those surveyed reported using the Internet or e-mail while on the job (Hipple \& Kosanovich, 2003). From an occupation standpoint, $79.6 \%$ of those surveyed who hold managerial and professional occupations reported using computers at work, and $65.8 \%$ of those surveyed in these occupations use the Internet at work. The most common uses of the computer in the workplace were to access the Internet generally or to exchange e-mail in particular, as indicated by the $71.8 \%$ of those surveyed who reported using their computer for these purposes. Although e-mail is facilitating what some see as a more efficient corporate communication system, it also gives the company the ability to more closely monitor those communications (Kovach, Conner, Livneh, Scallan, \& Schwartz, 2000).

As has been shown, monitoring and surveillance in general, and EM/S in particular, are part of the contemporary organizational landscape-and they tend to reflect a greater willingness within society to accept monitoring and surveillance today. Changes in technology are increasing both the prevalence of EM/S and organizations' 
capability to monitor their members. With little guaranteed protection from invasion of privacy, especially in the workplace, there is growing conflict between the rights of the individual and the rights of the organization when it comes to EM/S. Despite this fact, current laws do not provide much relief, and proposals for new legal guidelines have become a victim of the post-9/11 environment and are not up for reconsideration at this time. This conflict coupled with the constant development of new communication technologies, leaves organizations and their members without a clear direction to face in the confusing area of EM/S in the workplace.

\section{The Rationale for Modeling Electronic Monitoring / Surveillance}

Before proceeding to the development of the expanded model, this discussion of EM/S must also provide an understanding of why organizations employ surveillance and how it impacts employees and their communication within the organization. To that end, both the reasons for, and effects of, EM/S in the contemporary workplace will now be examined.

\section{Why EM/S in the Workplace?}

Monitoring has perhaps always been an aspect of work, although its use in the modern workplace is most strongly traced back to the concepts offered by Taylorism and scientific management. Computerized work measurement enables employers to more efficiently monitor individual employee productivity, even though telephone monitoring can be utilized to improve the quality of customer service. Video surveillance allows companies to prevent theft, fraudulent activities, and other workplace-related violations (Vaught, Taylor, \& Vaught, 2000). Software, driven by artificial intelligence, is now available that allow employers to view what is on an employee's computer at any given time (Meeks, 2000).

Some of the most common reasons for EM/S include: (a) performance reviews, (b) legal compliance, and (c) cost control (American Management Association, 2001, "Electronic Monitoring", 1999). Other cited reasons include: (a) protection of business information, (b) security and safety, and (c) lack of up-to-date legal regulation. Moreover, a 2001 (The Privacy Foundation) survey reasons 
include: (a) protection of business information, (b) security and safety, and (c) lack of up-to-date legal regulation. The Privacy Foundation (2001) also indicated that one of the top reasons for the surveillance by organizations is the low cost involved. According to this report, sales of employee-monitoring software were estimated at $\$ 140$ million a year, or approximately $\$ 5.25$ per year per employee monitored. One lesson issued by The Privacy Foundation (2001) report stated that the inexpensive nature of surveillance technology is a major factor in corporate decisions to utilize surveillance. Whatever the rationales for the use of EM/S technologies, they are having an impact on employees. It is with this understanding that several of the potential effects of EM/S in the workplace will now be addressed.

\section{Effects of EM/S in the Workplace}

Of all of the ways that the effects of EM/S in the workplace can be examined, two key and competing organizational elementsemployees' right to privacy and an organization's desire to control their employees - seem most beneficial to investigate here. At stake is an organization's ability to achieve stated goals and the individual employee's desire to be free from observation, especially in social (non-task) communication situations. These two elements will now be examined along with several additional potential outcomes of EM/S.

Stone and Stone (1990) treat privacy as the extent to which individuals believe they have control over their personal information and interactions with others. When examined from the perspective of the workplace, privacy presents a number of challenges. As Donnelly (1986) notes, workplace privacy is, at best, "a tenuous right, one that developed only recently and that, as recent events have shown, can easily succumb in the face of concern over other social problems and increasing technological capabilities" (p. 217). Although perceptions and expectations (see Rosenblum, 1991) of employee privacy in the workplace may vary from organization to organization, Duvall-Early and Benedict (1992) noted that individuals do have a need for privacy, thus the introduction of increased levels of surveillance in today's workplace may be problematic. Botan (1996) observes that increases in surveillance, whether they are expected or accepted, can result in panoptic effects--the degree to which individual employees feel they are controlled through various communication technologies.

Communication Theory, Vol. 16, No. 3 (August 2006): pg. 281-303. DOI. This article is (C Wiley and permission has been granted for this version to appear in e-Publications@Marquette. Wiley does not grant permission for this article to be further copied/distributed or hosted elsewhere without the express permission from Wiley. 
The issues surrounding employee monitoring have garnered renewed attention because of concerns over employee privacy rights. Nonetheless, as indicated earlier, the legal guarantee of privacy for employees does not exist. "American workers have almost no legal protection from employers who want to poke or prod into their personal lives" ("Privacy Invasions", 1993, p. 6). Alderman (1994) acknowledges that few workers realize that there are no federal laws that protect their privacy on the job. Additional concerns over employee privacy have been generated by advancements in technology, employer abuse of monitoring systems, and lack of legislation.

An additional concern also affecting employees is the fact that U.S. businesses typically abide by an "employment-at-will" doctrine (see Muhl, 2001), which allows organizations or the employees to terminate their working relation at any time, and without reason, when there is no official contract. This provides an organization with what Botan (1996) referred to as "legal freedom and ideological justification" for employing EM/S in the workplace (p. 295). It also offers employees the remedy of changing jobs when they are not comfortable with an organizations' use of EM/S. This doctrine also provides a glimpse into the growing tension between employee privacy and organizational control.

A key organizational concept since Weber (1947), organizational control is derived from the organizational need for employees to be subordinate to the overall organization in order for the organization to be achieve its goals (Barnard, 1968). Monitoring and surveillance represent a key method towards gaining this control. Edwards (1981) identified three strategies for control: (a) simple-direct, authoritarian control by management, (b) technological-found in the physical technology of the organization, and (c) bureaucratic control-systemic rules and policies that reward compliance and punish disobedience. The opportunity for EM/S use in both technological and bureaucratic strategies is readily apparent.

While there has been a shift towards more bureaucratic control, including the use of concertive control, in recent years (Barker, 1993), the advancements in communication technologies have allowed organizations to find a balance between both technological and bureaucratic control. Organizational policies allow for the

Communication Theory, Vol. 16, No. 3 (August 2006): pg. 281-303. DOI. This article is (C Wiley and permission has been granted for this version to appear in e-Publications@Marquette. Wiley does not grant permission for this article to be further copied/distributed or hosted elsewhere without the express permission from Wiley. 
establishment of control, and technology allows for those policies to be policed easily and effectively. This gives organizations the ability to monitor a variety of workers in a wide range of positions, from manufacturing to office-based knowledge workers. When organizations combine the technological and bureaucratic strategies through the use of new technologies and more restrictive organizational policies, employees are subject to a balanced attack of organization control through EM/S.

\section{Additional Potential Outcomes of EM/S}

Part of the rationale for developing a more detailed theoretical model can be found in the potential explanatory power of the various panoptic effects components on a variety of organizational outcomes. Much of the research available focuses primarily on measuring clerical work and the related performance-based outcomes (Stanton, 2000). Stanton and Weiss (2000) suggest that new research should explore the impact of monitoring and surveillance technology outcomes in addition to traditional performance outcomes. To this end, a brief overview of several potential outcomes that could benefit from the new model will now be presented. These include impact on workplace communication, workplace satisfaction, job performance, and perceived organizational fairness.

As Botan and McCreadie (1990) noted, when information technology is utilized for surveillance, it can affect organizational communication by reducing or limiting the need for individuals to communicate or by changing the specific type of communication involvement needed. Their study reports that, after implementing Internet tracking software to monitor employee use, one organization reduced the extracurricular or non-work related activities of its employees. The average time spent online fell from one hour a day to less than 15 minutes a day once employees were told that monitoring was occurring (Richmond, 2004). Upward communication can also be affected as surveillance limits the need for employees to report information to their supervisors-especially if this information has already been collected for processing. Foucault (1977) noted that this relationship demonstrates that the observed individual "is seen, but he does not see; he [sic] is the object of information, never the subject of communication" (p. 200). This seems to support an organization's use of EM/S. However, social (non-task) communication, which may be 
particularly vulnerable to EM/S, has been linked to positive organizational outcomes as well. Relationships that are built among co-workers through social communication can generate a number of positive workplace outcomes such as the development of strong group norms and cohesiveness (Keyton, 1999).

Beyond larger perceptual issues, Kallman (1993) indicates that there are many more negative aspects to EM/S, including increased levels of stress and mistrust, decreased job satisfaction and quality of work, and worsened customer service. Health problems such as stress, high tension, headaches, extreme anxiety, depression, anger, severe fatigue and musculoskeletal problems were also reported by Flanagan (1994) as a reaction to workplace monitoring. These problems may in turn lead to reduced workplace satisfaction (manifested as increased absenteeism), increased turnover, and decreased productivity (Levy, 1994). Along this line, satisfaction with social communication in the workplace also presents itself as a potentially important outcome of EM/S in the workplace. Nielson et al. (Nielson, Jex, \& Adams, 2000) noted that one's social relationships at work might be associated with job involvement, job satisfaction, and organizational commitment.

Job performance, defined here as an employee's ability to produce sufficient and adequate levels of quality work, could be influenced by EM/S. As noted earlier, Grant et al. (1988) found that monitored employees reported that quantity of work was more important to their employers than quality of work in overall performance. There is also a concern that surveillance has a negative effect on employer-employee relations (Balitis, 1998). These negative relations and the related low morale could in turn be affecting a company's bottom line, which is in direct contrast to one of the common goals of employee surveillance: improved productivity.

Thibaut and Walker's (1975) theory of procedural justice proffered that the amount of control individuals have over decision processes determines the fairness of decisions and outcomes. Looking at participation as an example of individual control, Kidwell and Kidwell (1996) found that one factor that helps develop perceived fairness of $\mathrm{EM} / \mathrm{S}$ is the degree of participation by employees in the process of developing EM/S policies. This was also noted by Ambrose and Alder (2000), who offer that fairness reactions can mediate the relationships between EM/S systems, work attitudes, and organizational outcomes.

Communication Theory, Vol. 16, No. 3 (August 2006): pg. 281-303. DOI. This article is (C Wiley and permission has been granted for this version to appear in e-Publications@Marquette. Wiley does not grant permission for this article to be further copied/distributed or hosted elsewhere without the express permission from Wiley. 
NOT THE PUBLISHED VERSION; this is the author's final, peer-reviewed manuscript. The published version may be accessed by following the link in the citation at the bottom of the page.

Having established not only a better understanding of the state of EM/S, but also clear indication of the importance of this issue in communication research, I now turn my focus to a review of the key theoretical contributions in the surveillance literature, and in particular Botan's theoretical presuppositions on the electronic panopticon in an effort to introduce an expanded model.

\section{Monitoring and Surveillance Theory}

\section{The Panopticon Metaphor}

The panopticon metaphor offers a useful tool to examine the effects of surveillance in the workplace. The concept of the panopticon originated from Jeremy Bentham's eighteenth century plan for a prison (Bentham, 1969). The design allowed for the observation of large numbers of prisoners from a central location without prisoners' knowledge of when and how often they were being observed. Foucault's (1977) theory of surveillance uses the panopticon as the centerpiece. Here, the subject under surveillance is seen by others, but cannot see the observers. This subject is the source of information rather than a participant in any communication. This can be likened to today's modern organization where its communication technology allows the organization to monitor employees without any overt signs of surveillance from the perspective of the employee.

The panopticon has often been a starting point for describing the type of relationship between organizations and individuals that EM/S can create within the workplace (Botan, 1996). The structure of the panopticon that Foucault (1977) describes has many parallels with the monitored workplace. Foucault sees the employment of panopticlike surveillance as an attempt to subjugate employees to the power of management. This design often instills a sense of powerlessness and fear among the observed. Additionally, the desired outcome, from the observer's perspective, allows for easier control of the observed. Vorvoreanu and Botan (2000) note another similarity: Employees are isolated in their own communication environment, which, unlike the physical barriers of the panoptic prison, are more electronic in nature.

\section{The Information Panopticon}

Zuboff (1988) gives us the term information panopticon and argues that management control is freed from the constraints of time

Communication Theory, Vol. 16, No. 3 (August 2006): pg. 281-303. DOI. This article is @ Wiley and permission has been granted for this version to appear in e-Publications@Marquette. Wiley does not grant permission for this article to be further copied/distributed or hosted elsewhere without the express permission from Wiley. 
and space due to the use of electronic systems capable of collecting information. A distinct difference is also noted between the panopticon of Bentham (1969) and the "information panopticon," where an individual can be both the observer and the observed. Although an employee might be under observation by a manager, that same manager might be under observation by another individual higher up in the hierarchy of the organization. Zuboff (1988), and later Botan (1996), observe that the compartmentalization of the workers in the information workplace can be accomplished without the need for physical structures.

\section{The Electronic Panopticon}

To extend this research, Botan (Botan, 1996; Botan \& McCreadie, 1990) conceived a continuum upon which individual workers either have control of or are controlled by the information technology they utilize. The point at which the individuals become controlled is referred to as the panoptic threshold. This threshold is the point where the information technology becomes a surveillance technology. Botan posits this threshold is unique to each situation, but is determined by the same four factors: panoptic potential of the technology, management policy, employee perception, and maturation. Panoptic potential of an information technology refers to its capability to facilitate surveillance. Botan and McCreadie (1990) maintain that this potential is determined by at least four characteristics: degree of visibility, degree of invisibility, degree of record production, and degree of technologically driven data analysis.

The management policy factor (Botan, 1996; Botan \& McCreadie, 1990) is concerned with how policy determines how and when technology with surveillance capabilities can be used for that purpose. Zuboff (1988) notes that how these technologies are used is often a function of such management policies. These information technologies, which give workers greater access to information, also provide management with "a deeper level of transparency to activities that had been either partially or completely opaque" (p. 9).

The third factor, worker perceptions (Botan, 1996; Botan \& McCreadie, 1990), is concerned with how aware employees are that they are being surveilled. In order for the power relationships to be effective in a surveillance relationship, some awareness on the part of

Communication Theory, Vol. 16, No. 3 (August 2006): pg. 281-303. DOI. This article is @ Wiley and permission has been granted for this version to appear in e-Publications@Marquette. Wiley does not grant permission for this article to be further copied/distributed or hosted elsewhere without the express permission from Wiley. 
the individual is necessary. Surveillance can occur without this awareness, but then it lacks the panoptic effect. The perception alone that one may be surveilled, even if it is not actually occurring, can be a powerful tool for management and can have serious potential impacts for the individual.

Finally, maturation (Botan, 1996; Botan \& McCreadie, 1990) refers to the integration of the first three factors such that they work together to increase the panoptic environment. Botan (1996) defines maturation as "how effectively surveillance technology has become integrated with policies" and can be illustrated when "surveillance procedures are well established, legal or union opposition has been resolved, and the results of surveillance are an acknowledged part of organizational decision-making and disciplinary proceedings" (p. 300). Smith (1989) pointed out that it takes time for high panoptic potential to be incorporated into management policies on surveillance, and the related power connection can become more developed as the individual perceives higher levels of surveillance. Organizations with highly developed surveillance polices still need time to incorporate new technologies into the overall surveillance equation.

While this model has several strengths, it also has a number of limitations. First, although Botan (1996) notes that an employee's perceptions are probably the most important factor of the model, they comprise only a single part of his model, which limits the potential impact of these perceptions. This provides inadequate representation for such a vital element. It seems far more reasonable to expect that perception is completely embedded within the panoptic effect and is consequently an important influence on any variable that helps in explaining panoptic effect. Failing to account for the full impact of perception limits any understanding of potential panoptic effects in the workplace. It follows logically, then, that any new model must attempt to identify the interwoven nature between perception and panoptic effect.

Second, Botan's (1996) model is limited to the exploration of communication surveillance in the workplace in general, and does not break up its analysis of the types of communication in the workplace to take into account that both task-based and social-based (non-task) communication can, and do, occur. Once again, the Botan model provides good and broad brushstrokes, which offer a valid frame for

Communication Theory, Vol. 16, No. 3 (August 2006): pg. 281-303. DOI. This article is @ Wiley and permission has been granted for this version to appear in e-Publications@Marquette. Wiley does not grant permission for this article to be further copied/distributed or hosted elsewhere without the express permission from Wiley. 
understanding panoptic effects, but is less than representative of the whole. The reality is that employees are not automatons interacting in a vacuous workplace. Therefore, communication in the workplace is not initiated from universal intention and does not serve universal ends. It is complex, and as such, the specific nature of workplace communication bears influence on any potential panoptic effect. The new model proffered here serves as an initial attempt to rectify this issue by focusing on the socially driven aspects of workplace communication. The result, while not wholly inclusive, creates the basis of an inductive modeling approach to EM/S in the workplace, which in turn allows for a more comprehensive understanding of this critical organizational issue.

Third, Botan's management policies' factor simply addresses how and when EM/S can be used rather than looking at any direct impact on employees or their policy perceptions. This focus appears to unduly limit consideration of the potential an EM/S policy could have on employees. It is important to note that the existence of such a policy could result in panoptic effects. Beyond that, Botan's (1996) model does not address the potential impact of the characteristics of a given policy, such as its currency, thoroughness, and policy perspective, which I shall discuss below. To improve our understanding, any new model must account for such factors.

Finally, the maturation factor seems to be misplaced. This factor would be more appropriately viewed from an interaction perspective rather than as an independent component in the model, as is the case in Botan's (1996) model. In his model, it appears to be artificially removed from other components within which it is likely an embedded element. By linking only technology and management policies, the maturation factor is seen to play a more limited role than may actually be the case.

From the early prison concepts of Bentham (1969) to Botan's (1996) panoptic effects model, our understanding, as demonstrated here, regarding the impact of privacy, monitoring, and surveillance on communication has grown tremendously. Previous research and current trends in the use of EM/S have drawn needed attention to this field and have raised awareness of its significance to the understanding of communication in the workplace. There is more, however, to be explored. Increasing organizational use of EM/S 
necessitates the development of a new theoretical model that improves the understanding of panoptic effects in the organizational setting. A more specific model, extending Botan's (1996) work, while concurrently addressing its limitations, is needed in order to more accurately assess the impact of EM/S in the workplace. In the next section, I propose an interactive model, which I call the structuralperspective model of EM/S. It is designed to delve deeper into related communication and organizational aspects of EM/S.

\section{Toward a Structural-Perceptual Model of Electronic Monitoring and Surveillance}

Utilizing previous research and the panoptic effect model (Botan, 1996; Botan \& McCreadie, 1990) as a basis, I will now discuss the structural-perspective model (see Figure 1 ). Its design is comprised of three primary components: communication technologies, organizational factors, and organizational EM/S policies. ${ }^{4}$ The model proposes that these components lead to panoptic effects in the organizational environment. The new model does share some similarities with Botan's (1996) model, as well as some of Zuboff's (1988) contributions. First, for example, the surveillance potential of a technology remains as a key consideration. Second, organizational policies on EM/S also play a key role in the model. However, unlike Botan's previous model of panoptic effects where employee perceptions were considered as a separate element, the new model incorporates employee perceptions into its consideration of all three of its primary components. Furthermore, maturation, like employee perceptions of surveillance, is no longer considered as a separate component, but instead is integrated into the overall consideration of all components of the model.

I will now present each of the three components communication technology, organizational factors, and organizational EM/S policies - by examining both the structural and perceptual elements involved. The model proposes that there are potential structural elements in communication technology, organizational factors, and organizational policies that add to the panoptic potential associated with each. In addition to these structural elements, each component has a number of perceptual elements, based on the subjective views of employees in the organizational environment, 
which contribute to the perceived surveillance potential of each component. Both the structural and perceptual elements represent separate, but distinct pieces of the puzzle, and it is only through the analysis of the two combined that a more accurate understanding of the impact of EM/S in the workplace will be possible. I turn now to a discussion of the underlying structural and perceptual elements of each of the three components.

\section{Overall Panoptic Effect Potential of Communication Technology}

Rather than looking only at a communication technology's potential to be used as a surveillance tool, this new model looks at both the inherent features of, and the user's interaction with the communication technology. The technology component of this model, although similar to the technology factor of Botan's (1996) model, has two main elements (as compared to the singular focus of the Botan model): the archivability potential of a technology (i.e., its capability to record and store messages) and the perceived surveillance potential of a communication technology (i.e., organizational members' perceptions about how a given technology might be used as a surveillance tool).

\section{Archivability: Structural Considerations}

The structural element- the archivability potential of a technology - is the result of the interaction of two communication technology characteristics: a technology's level of - synchronicity and its message format (see Finn \& Lane, 1998; see Lievrouw \& Finn, 1990). Both of these characteristics have the ability to increase or decrease the likelihood that a particular communication technology can archive messages. The more synchronous a communication technology is, the less likely it is that its messages will be archived because archiving the messages sent with highly synchronous technology requires a high level of resources, and because of some of the legalities associated with intercepting messages in transit. The messages sent with asynchronous technologies are more likely to be archived because archiving routinely occurs in the regular process of communicating such messages and does not require any additional resources. Therefore, organizational messages that have been

Communication Theory, Vol. 16, No. 3 (August 2006): pg. 281-303. DOI. This article is @ Wiley and permission has been granted for this version to appear in e-Publications@Marquette. Wiley does not grant permission for this article to be further copied/distributed or hosted elsewhere without the express permission from Wiley. 
NOT THE PUBLISHED VERSION; this is the author's final, peer-reviewed manuscript. The published version may be accessed by following the link in the citation at the bottom of the page.

archived represent a greater potential for surveillance of employees and their communication.

\section{Perceived Surveillance Potential from Communication Technology: Perceptual Considerations}

On the perceptual side of the model's technology component, the perceived surveillance potential of communication technology is defined as the total potential for monitoring and surveillance that is explained through the use of, understanding of, and surveillance beliefs about a communication technology, from the organizational member's perspective. This is different from Botan's (1996) notion of the surveillance potential of a technology in that the focus in this new model is a technology's perceived potential for surveillance rather than the actual surveillance capability of a communication technology. In this new model, there are four key perceptual factors - frequency of use, comfort, proficiency, and beliefs about a communication technology's surveillance capabilities - that influence the perceived surveillance potential of a communication technology. Each of these elements examines a different aspect of an individual's use of a particular communication technology, and they are discussed below.

Frequency of use is concerned with how often an individual uses a particular technology in the normal course of work. As an individual increases his or her use of a particular communication technology, his or her perception of the level of that technology's surveillance potential decreases, especially as his or her use of the technology becomes second nature, or what Timmerman calls "mindlessness" (2002).

Comfort with a technology focuses on the extent to which an individual is at ease with using a particular communication technology. As an individual becomes more comfortable using a particular communication technology and develops a certain "trust" in that technology, his or her apprehension about the technology decreases, and he or she perceives that its surveillance potential is reduced.

Proficiency represents a longer-term aspect where a user has achieved a certain level of competence using a technology. As with frequency of use and comfort, increased proficiency leads an individual to select a particular communication technology out of habit or mindless decision (Timmerman, 2002). Therefore, as an individual's

Communication Theory, Vol. 16, No. 3 (August 2006): pg. 281-303. DOI. This article is (C) Wiley and permission has been granted for this version to appear in e-Publications@Marquette. Wiley does not grant permission for this article to be further copied/distributed or hosted elsewhere without the express permission from Wiley. 
proficiency with a particular communication technology increases, the perceived surveillance potential of that technology is diminished.

Surveillance beliefs. Finally, the belief about a communication technology's surveillance capabilities is influenced by whether an employee is knowledgeable or aware of a communication technology's surveillance capability in addition to its communication function. This notion is similar to the surveillance potential of a technology in Botan's (1996) model, but here it is the user's perceptions of a technology's capabilities, and his or her knowledge of previous instances of its use as a surveillance tool that are of interest rather than the technology's actual surveillance capabilities, as is the case in Botan's model.

Frequency of use, comfort, and proficiency with communication technology, and technology in general, represent commonly used variables in computer-mediated communication studies in organizations. Previous research utilizing these variables has looked at employee attitudes toward computer-based technology, telephone usage, and preparedness of organizational members with the technology (Coover, 1992; Galinsky, 1997; Guha, 2003). In this essay, these variables are offered for a basic understanding of the impact of communication technology on EM/S and do not represent an exhaustive list, but rather a starting point from which to understand the impact of communication technology on surveillance potential.

Each of the structural and perceptual elements, alone or in conjunction with the other affects the overall perceived surveillance potential of a communication technology. As Carlson and Zmud (1999) found, user experiences can impact how a technology is used. This is turn can affect users' perceptions about whether a communication tool can also be utilized as a surveillance tool. Therefore, based on this idea, the following proposition is offered:

P1 - The overall panoptic effects potential of communication technology is created through the combination of the archivability and perceived surveillance potentials.

The structural and perceptual elements of this first model component - communication technology - can then be conceptually combined to explain the overall panoptic effect potential of communication technologies. It is the combined effect of both archivability and perceived surveillance capability of a communication

Communication Theory, Vol. 16, No. 3 (August 2006): pg. 281-303. DOI. This article is @ Wiley and permission has been granted for this version to appear in e-Publications@Marquette. Wiley does not grant permission for this article to be further copied/distributed or hosted elsewhere without the express permission from Wiley. 
NOT THE PUBLISHED VERSION; this is the author's final, peer-reviewed manuscript. The published version may be accessed by following the link in the citation at the bottom of the page.

technology that leads to a better understanding of the overall panoptic effect from communication technologies.

\section{Overall Panoptic Effect Potential from Organizational Factors}

The second component of the structural-perceptual EM/S model looks at the role of organizational factors on the potential for surveillance. These factors include inherent aspects of an organization, which are again conceptually organized in this model as structural and perceptual elements.

\section{Organizational Need for Surveillance: Structural Considerations}

The structural elements include organizational centralization, organizational levels, and organizational size. First, an organization's centralization is defined here as the degree to which centralized management has control over decision-making and employees (Fayol, 1949). Here organizations vary across continuum from "very decentralized" to "very centralized" with the latter potentially being more conducive to EM/S. An organization that handles a high volume of internal or external communication needs to keep closer tabs on its employees than one with a lower volume of communication in order to limit potential abuse of organizational resources for personal use. Second, the number of hierarchical levels in the organization is relevant. As Fayol (1949) noted, an organization is most effective and efficient when managers are responsible for a limited number of employees. Surveillance technology allows managers to monitor more employees than would otherwise be possible, reducing the number of managers required for a given number of employees. This is also related to the organizational size. Size is a key element because larger organizations have different needs or requirements for EM/S than do smaller organizations. The larger an organization becomes, the more its need for EM/S use increases so that the organization can maintain control of its employees. McGregor (1960) noted in Theory X that managers often incorrectly believe that their responsibility regarding their employees is to direct their efforts, control their actions, and modify their behaviors to fit the needs of the organization. Without this type of management, the theory states that employees would be passive, even resistant to organizational needs. EM/S in essence has given managers another tool to achieve control. The combination of all

Communication Theory, Vol. 16, No. 3 (August 2006): pg. 281-303. DOI. This article is (c) Wiley and permission has been granted for this version to appear in e-Publications@Marquette. Wiley does not grant permission for this article to be further copied/distributed or hosted elsewhere without the express permission from Wiley. 
of these elements (centralization, levels, and size) is what gives rise to the organizational need for surveillance. I will now look at the perceptual element of organizational factors

\section{Surveillance Potential from Organizational Factors: Perceptual Considerations}

The perceptual element of organizational factors is concerned with the users' perspective of whether they consider some of the organizational factors of their workplace to be possible indicators that surveillance is occurring. In effect, it proffers that some elements of an employee's organizational culture ${ }^{3}$ lead to whether or not he or she believes the potential for surveillance is increased as a result. Organizational management style and organizational communication climate, both parts of an organization's culture, influence the perceived surveillance potential in an organization. Different management styles influence employees' perceptions of workplace surveillance in different ways. "Managers who tend to trust their employees would be less likely to monitor messages than would managers who tend to be suspicious of their employees" (Weisband \& Reinig, 1995, p. 44). Organizational communication climate, defined here as the degree of openness and freedom employees have to communicate with one another, can assist in predicting some panoptic effects. Those organizations that want and promote an open and communicative workplace are less likely to employ an EM/S system for fear that it may stifle communication and lead to other negative outcomes. As a result, organizations with a more open communication climate are likely to have a lower perceived surveillance potential from organizational factors.

This understanding leads to the following proposition:

P2 - The combination of organizational need and perceived surveillance form the overall panoptic effects potential from organizational factors.

It is the combined effect of both structural and perceptual elements that leads to a better understanding of the overall panoptic effect from organizational factors.

Communication Theory, Vol. 16, No. 3 (August 2006): pg. 281-303. DOI. This article is @ Wiley and permission has been granted for this version to appear in e-Publications@Marquette. Wiley does not grant permission for this article to be further copied/distributed or hosted elsewhere without the express permission from Wiley. 


\section{Overall Panoptic Effect Potential from Organizational EM/S Policies}

The final major component - organizational policies - of the structural-perceptual model of EM/S also has both structural and perceptual elements that contribute to the overall panoptic effect. This component is defined as the overall panoptic potential that is the result of factors inherent to an organization's EM/S policy and its implementation, such as the policy perspective, clarity, thoroughness, and enforcement of these policies. It should be noted that organizations that do not have an EM/S policy do not have a panoptic effect potential from organizational EM/S policies. ${ }^{5}$ In such cases, this component is dropped from the model. For those organizations that do have an EM/S policy in some form or another, this component plays an important role in the overall model.

\section{Policy Restrictiveness: Structural Considerations}

Policy restrictiveness, the structural element of the overall panoptic effect potential from organizational policies, deals with three areas: (a) EM/S policy perspective, (b) the currency of the policy, and (c) the thoroughness of the policy. The EM/S policy perspective examines an organization's stance on EM/S policy, and is based on Weisband and Reinig's (1995) classifications of organizational policy standpoints. Here, it is theorized that policies lie on a continuum from those that emphasize an organization's right-to-monitor to those that reveal a "hands-off" attitude, where sometimes no policy is in place. Those organizations that establish an EM/S policy closer to the rightto-monitor end of the continuum have more restrictive policies regarding communication technology usage, while organizations that establish policies leaning towards the hands-off end have less restrictive policies. For example, an organization with a strict right-tomonitor policy and also restricts Internet access at work for personal use may actively monitor Internet usage by employees. Second, currency is determined by the age of the current version of a policy, or the time since it was most recently updated to reflect changes in the law, technology, or an organization's stance on EM/S. Policies that are more up-to-date tend to reflect the latest legal and legislative changes as well as the introduction of newer communication technologies into the organizational environment, which in turn leads to greater policy 
restrictiveness. Finally, thoroughness looks at whether or not a policy is explicit in both the details of using specific technology and the specific consequences for violations of the policy. Those policies that are more thorough in their treatment of the current technology, laws, and consequences have higher levels of restrictiveness.

\section{Perceived Surveillance Potential from EM/S Policy: Perceptual Considerations}

The perceived surveillance potential of an EM/S policy is influenced by the perceptual elements in this component. These elements are concerned with how much an organization's EM/S policy impacts an individual's perception that he or she is monitored or surveilled in the workplace. Here, there are two important subelements of interest that potentially influence the perceived surveillance potential of an EM/S policy: (a) the type of EM/S policy, and (b) the level of enforcement of an EM/S policy. First, the type of EM/S policy is concerned with employee perceptions of where the policy falls on the continuum (right-to-monitor to hands-off). A policy that is clearly seen as a right-to-monitor policy will result in greater perceived surveillance potential. Vague or poorly written policies also have some perceived surveillance potential, while hands-off policies have little or no perceived surveillance potential. Second, enforcement is concerned with the employee's belief about what the enforcement of an EM/S policy implies about that policy. Therefore, the more an employee believes that enforcement of an EM/S policy indicates a right-to-monitor policy, the greater the perceived surveillance potential of that policy. These two elements, when combined, provide valuable insight into the perceived surveillance potential of an EM/S policy, and indicate that structural elements are an important part of the overall picture. With this in mind, the following proposition is offered:

P3 - The combination of policy restrictiveness and the perceived surveillance potential of an EM/S policy give rise to the overall panoptic effects potential of organizational EM/S policies.

Together, the restrictiveness of EM/S policies and the perceived surveillance potential of an EM/S policy impact the overall panoptic effect potential from organizational EM/S policies. The characteristics of a policy and an employee's understanding of the policy provide a 
more comprehensive picture of the panoptic effect potential of organizational EM/S policies.

\section{Moderating Variable}

\section{Perceived Surveillance Concern}

As depicted in the new model, perceived concern for surveillance may moderate how individuals perceive EM/S practices and policies within the organization. An individual may believe that EM/S is very prominent in the organization, but because they have little concern for this issue, monitoring and surveillance will have little effect on any of the outcomes that could be measured in future research, such as communication policy, organizational control, organizational fairness, job performance, workplace satisfaction, and workplace communication. One possible explanation of variations in concern might be found by examining an employee's position within an organization; certain positions may foster more openness to various types of EM/S. A lack of employee concern about EM/S could, in effect, eliminate panoptic effects - either intentional or not - that could result from the presence of EM/S within the organization. Conversely, an individual who has a high concern regarding potential surveillance in the workplace may experience a greater panoptic effect than would normally be attributed by the model alone. Depending on the prominence of such concern, organizational leaders may see a lack of employee concern about EM/S as a green light for increased levels of surveillance, whereas great concern might be reason to question implementing EM/S. As such, the following proposition is presented:

P4 - The relationship between key outcomes and the overall panoptic effect potential (from communication technology, organizational factors, and policy) is moderated by employee concern for surveillance.

In summary, this new model for studying panoptic effects builds upon previous research, especially the work by Botan (1996). It presents a potentially more comprehensive method of determining panoptic effects while maintaining most of the key components and concepts from previous theorizing. Each component has both structural and perceptual elements that offer a more balanced approach to understanding the overall picture of panoptic effects.

Communication Theory, Vol. 16, No. 3 (August 2006): pg. 281-303. DOI. This article is (c) Wiley and permission has been granted for this version to appear in e-Publications@Marquette. Wiley does not grant permission for this article to be further copied/distributed or hosted elsewhere without the express permission from Wiley. 
NOT THE PUBLISHED VERSION; this is the author's final, peer-reviewed manuscript. The published version may be accessed by following the link in the citation at the bottom of the page.

\section{Limitations and Future Directions}

While the current essay offers a model that extends Botan's (1996) work and addresses many of the previous model's limitations, the model proposed here is not without limitations. These limitations indicate a call for continued work in this direction in an attempt to refine this theory. First, the current model focuses on social communication (non-task) within the workplace. As such, it is not concerned with the formal, day-to-day communication that takes place in the typical organization. This narrower focus may ignore key elements that may contribute to the overall panoptic effect. This may be especially relevant when looking at the potential moderating variable of surveillance concern because an employee who uses communication technology for work purposes may have little concern for monitoring or surveillance of that type of communication. Future research could examine the differences in employee surveillance concern between social and formal workplace communication. In turn, this research could lead to a more refined overall model that considers workplace communication in general.

Second, some of the individual elements of the communication technology component of the model may not accurately assess the surveillance potential of a technology. Increased frequency of use, comfort, and proficiency with a communication technology may bring about more awareness on the part of the user, and in turn, a greater perceived surveillance potential as he or she may be very aware of a technology's EM/S capabilities. Additional individual elements not presented here may also provide a clearer picture of this component of the model.

Third, the potential outcomes suggested in this essay only represent a small portion of what could be analyzed. Other potential outcomes that could realize an impact from workplace EM/S should also be investigated in future endeavors, including: (a) trust specifically individual trust in the organization as impacted by the use of EM/S, (b) loyalty - how will the use of EM/S impact an individual's connection to the organization, and (c) identification - does the use of EM/S impact how individuals perceive themselves, both as individuals and as organizational members. These additional outcomes could provide more insight into the issues of organizational fairness and the importance of surveillance concern.

Communication Theory, Vol. 16, No. 3 (August 2006): pg. 281-303. DOI. This article is @ Wiley and permission has been granted for this version to appear in e-Publications@Marquette. Wiley does not grant permission for this article to be further copied/distributed or hosted elsewhere without the express permission from Wiley. 
Finally, this model in no way addresses what may be of greater concern to organizations, individuals, and communication in general: whether or not EM/S should be utilized in organizations. As the United States struggles with the balancing act between greater personal freedoms and the need for greater security and safety highlighted in the USA PATRIOT Act debates, similar conversations are not occurring in organizations today. This concern must be addressed.

While there are some important limitations, the model also offers some key potential benefits. First, it may help determine what workers perceive as the most prevalent source of panoptic effects in the workplace. With this knowledge, future research may be able to gain a better understanding of the importance of employee perceptions about the source of panoptic effects in the workplace in EM/S. The model could also provide organizations with a more accurate picture of where EM/S efforts will have the most impact on employees. Second, this model may present a roadmap of sorts, which would allow organizations to find a balance between the need for organizational control and employees' desire for communication privacy. Seeking this balance could also reduce the effect of the moderating variable, surveillance concern, as the organization may be perceived as acting in a fair and reasonable manner. Finally, future research is currently underway that will attempt to test portions of the proposed model described here. As part of this process, additional information regarding related issues of surveillance will also be gathered including learning about potential reactions (and associated actions) to surveillance. It is hoped that the overall picture generated by this research will advance our understanding of EM/S in the workplace.

\section{Conclusion}

From the early concept of Bentham's Panopticon to Botan's (1996) update of the concept in the electronic panopticon, there has been a significant amount of research in the area. However, more work is still needed. As communication technology continues to evolve alongside changes in the contemporary workplace, these issues will become even more important to both employees and managers. The proposed model seeks to extend the research and our knowledge of the fundamental issues of privacy and surveillance in the workplace, and to understand the roles that technologies, organizational factors, and EM/S policies play. The key components comprising the overall

Communication Theory, Vol. 16, No. 3 (August 2006): pg. 281-303. DOI. This article is (C) Wiley and permission has been granted for this version to appear in e-Publications@Marquette. Wiley does not grant permission for this article to be further copied/distributed or hosted elsewhere without the express permission from Wiley. 
panoptic effect potential contain inherent structural elements as well as the individual elements that employees perceive. It is through the combination of these elements that this model hopes to provide a clearer understanding of panoptic effect potential of EM/S in the workplace as it relates to organizational communication. The model extends extant knowledge by differentiating specific types of panoptic effects. These effects, either alone, or by interacting with each other, present a more precise picture of panoptic effects and their potential impact on a variety of workplace outcomes.

\section{References}

1. Alderman, L. (1994, December). Safeguard your secrets from your boss. Money, 31-32.

2. Ambrose, M. L., \& Alder, G. S. (2000). Designing, implementing, and utilizing computerized performance monitoring: Enhancing organizational justice. Research in Personnel and Human Resource Management, 18, 187-219.

3. American Management Association. (2001). AMA survey: Workplace monitoring and surveillance. New York, NY.

4. American Management Association. (2003). E-mail rules, policies and practices survey. New York, NY.

5. American Management Association. (2005). 2005 Electronic monitoring \& surveillance survey. New York, NY.

6. Balitis, J. J. (1998). Care needed with electronic monitoring. Business Journal (Phoenix), 18(21), 71.

7. Barker, J. R. (1993). Tightening the iron cage: Concertive control in selfmanaging teams. Administrative Science Quarterly, 38, 408-437.

8. Barnard, C. (1968). The functions of the executive. Cambridge, MA: Harvard University Press.

9. Bentham, J. (1969). A Bentham reader. New York: Pegasus.

10. Botan, C. H. (1996). Communication work and electronic surveillance: A model for predicting panoptic effects. Communication Monographs, 63, 293-313.

11. Botan, C. H., \& McCreadie, M. H. (1990). Panopticon: Workplace of the information society. Paper presented at the Annual Conference of the International Communication Association, Dublin, Ireland.

Communication Theory, Vol. 16, No. 3 (August 2006): pg. 281-303. DOI. This article is (C Wiley and permission has been granted for this version to appear in e-Publications@Marquette. Wiley does not grant permission for this article to be further copied/distributed or hosted elsewhere without the express permission from Wiley. 
NOT THE PUBLISHED VERSION; this is the author's final, peer-reviewed manuscript. The published version may be accessed by following the link in the citation at the bottom of the page.

12. Carlson, J. R., \& Zmud, R. W. (1999). Channel expansion theory and the experimental nature of media richness perceptions. Academy of Management Journal, 42, 153-170.

13. Coopman, S., Watkins Allen, M., \& Hart, J. (2003). Submit, resist, or subvert? Organization member's responses to electronic surveillance. Paper presented at the Association of Internet Researchers 4.0 Conference, Toronto, Canada.

14. Coover, D. (1992). Construct and criterion-related validity of the AdultAttitudes Toward Computers Survey for a sample of professional nurses. Educational and Psychological Measurement, 52, 653-661.

15. Cozzetto, D. A., \& Pedeliski, T. B. (1997). Privacy and the workplace: Technology and public employment. Public Personnel Management, 26, 515-527.

16. Donnelly, H. (1986, March 21). Privacy in the workplace. Editorial Research Reports, 1, 214.

17. Duvall-Early, K., \& Benedict, J. O. (1992). The relationship between privacy and different components of job satisfaction. Environment and Behavior, 24, 670-679.

18. Edwards, R. C. (1981). The social relations of production at the point of production. In M. Zey- Ferrell \& M. Aiken (Eds.), Complex organizations: Critical perspectives (pp. 156-182). Glenview, IL: Scott Foreman.

19. Electronic monitoring: Benefit and threat. (1999). Worklife, 12(2), 6.

20. Fayol, H. (1949). General and industrial management (C. Storrs, Trans.). London: Pitman.

21. Finn, T. A., \& Lane, D. R. (1998). A conceptual framework for organizing communication and information systems. Paper presented at the Annual International Communication Association Conference, Jerusalem.

22. Flanagan, J. (1994). Restricting electronic monitoring in the private workplace. Duke Law Journal, 43, 1256-1281.

23. Foucault, M. (1977). Discipline and punish: The birth of prison (A. Sheridan, Trans.). New York: Pantheon.

24. Galinsky, M. J. (1997). Connecting group members through telephone and computer groups. Health \& Social Work, 22, 181-188.

Communication Theory, Vol. 16, No. 3 (August 2006): pg. 281-303. DOI. This article is (c) Wiley and permission has been granted for this version to appear in e-Publications@Marquette. Wiley does not grant permission for this article to be further copied/distributed or hosted elsewhere without the express permission from Wiley. 
NOT THE PUBLISHED VERSION; this is the author's final, peer-reviewed manuscript. The published version may be accessed by following the link in the citation at the bottom of the page.

25. Grant, R., Higgins, C. A., \& Irving, R. H. (1988). Computerized performance monitors: Are they costing you customers? Sloan Management Review, Spring, 39-45.

26. Guha, S. (2003). Are we all technically prepared? Teacher's perspective on the causes of comfort or discomfort in using computers at elementary grade teaching. Information Technology in Childhood Education Annual, 15, 317-349.

27. Hipple, S., \& Kosanovich, K. (2003). Computer and Internet use at work in 2001. Monthly Labor Review, 126(2), 26-35.

28. Kallman, E. (1993). Electronic monitoring of employees: Issues and guidelines. Journal of Systems Management, June, 17-21.

29. Keyton, J. (1999). Group communication: Process and analysis. Mountain View, CA: Mayfield.

30. Kidwell, R. E., \& Kidwell, L. A. (1996). Evaluating research on electronic surveillance: A guide for managers of information technology. Industrial Management \& Data Systems, 96, 8-14.

31. Kovach, K. A., Conner, S. J., Livneh, T., Scallan, K. M., \& Schwartz, R. L. (2000). Electronic communication in the workplace - Something's got to give. Business Horizons, 43(4), 59- 64.

32. LeVine, S. (1984). The fight from ambiguity. Chicago: University of Chicago Press.

33. Levy, M. (1994). The electronic monitoring of workers: Privacy in the age of the electronic sweatshop. Legal Reference Service Quarterly, 14(3), 5-56.

34. Lievrouw, L., \& Finn, T. A. (1990). Identifying the common dimensions of communication: The communications systems model. In B. Ruben \& L. Lievrouw (Eds.), Mediation, information and communication: Information and behavior (Vol. 3, pp. 37-65). New Brunswick, NJ: Transaction.

35. McGreggor, D. (1960). The human side of enterprise. New York: McGrawHill.

36. Meeks, B. N. (2000, December 4). Big boss is watching you: Workplace snooping remains privacy quandary. Newsweek Retrieved May 9, 2006, from http://msnbc.msn.com/id/3078850/497887.asp

37. Muhl, C. J. (2001). The employment-at-will doctrine: Three major exceptions. Monthly Labor Review, 124(1), 3-12.

Communication Theory, Vol. 16, No. 3 (August 2006): pg. 281-303. DOI. This article is @ Wiley and permission has been granted for this version to appear in e-Publications@Marquette. Wiley does not grant permission for this article to be further copied/distributed or hosted elsewhere without the express permission from Wiley. 
NOT THE PUBLISHED VERSION; this is the author's final, peer-reviewed manuscript. The published version may be accessed by following the link in the citation at the bottom of the page.

38. Nebeker, D. M., \& Tatum, B. C. (1993). The effects of computer monitoring, standards, and rewards on work performance, job satisfaction and stress. Journal of Applied Social Psychology, 23, 508536.

39. Nielson, I. K., Jex, S. M., \& Adams, G. A. (2000). Development and validation of scores on a two-dimensional workplace friendship scale. Educational and Psychological Measurement, 60, 682-643.

40. Privacy invasions. (1993, December 1). USA Today (Magazine), p. 6.

41. Richmond, R. (2004, January 12). It's 10 a.m.: Do you know where your workers are? The Wall Street Journal, pp. R1, R4.

42. Rosenblum, M. F. (1991). Security vs. privacy: An emerging employment dilemma. Employee Relations Law Journal, 17, 81-99.

43. Rule, J., \& Brantley, P. (1992). Computerized surveillance in the workplace: Forms and distributions. Sociological Forum, 7, 405-423.

44. Smith, M. R. (1989). Technologizing office work. Society, 65-72.

45. Stanton, J. M. (2000). Reactions to employee monitoring: framework, review, and research directions. Human Performance, 13, 85-113.

46. Stanton, J. M., \& Weiss, E. M. (2000). Electronic monitoring in their own words: An exploratory study of employees' experiences with new types of surveillance. Computers in Human Behavior, 16, 423-440.

47. Stone, E. F., \& Stone, D. L. (1990). Privacy in organizations: Theoretical issues, research findings, and protection mechanisms. Research in Personnel and Human Resource Management, 8, 349-411.

48. The Privacy Foundation. (2001). The extent of systemic monitoring of employee e-mail and Internet use. Denver, CO: Schulman, A.

49. Thibaut, J. W., \& Walker, L. (1975). Procedural justice: A psychological analysis. New York: Erlbaum/Halstead.

50. Timmerman, C. E. (2002). The moderating effect of mindlessness/mindfulness upon media richness and social influence explanations of organizational media use. Communication Monographs, 69, 111-131.

51. U.S. Census Bureau. (2001). Computer and Internet use in the United States: September 2001 (PPL-175). Retrieved May 9, 2006, from http://www.census.gov/population/www/socdemo/computer.html

Communication Theory, Vol. 16, No. 3 (August 2006): pg. 281-303. DOI. This article is @ Wiley and permission has been granted for this version to appear in e-Publications@Marquette. Wiley does not grant permission for this article to be further copied/distributed or hosted elsewhere without the express permission from Wiley. 
NOT THE PUBLISHED VERSION; this is the author's final, peer-reviewed manuscript. The published version may be accessed by following the link in the citation at the bottom of the page.

52. Vaught, B. C., Taylor, R. E., \& Vaught, S. F. (2000). The attitudes of managers regarding the electronic monitoring of employee behavior: Procedural and ethical considerations. American Business Review, 18, 107-114.

53. Vorvoreanu, M., \& Botan, C. H. (2000). Examining electronic surveillance in the workplace: A review of theoretical perspectives and research findings. Paper presented at the Annual International Communication Association Conference, Acapulco, Mexico.

54. Weber, M. (1947). The theory of social and economic organizations (T. Parsons, Trans.). New York: Free Press.

55. Weisband, R. P., \& Reinig, B. A. (1995). Managing user perceptions of email privacy. Communications of the ACM, 38, 40-47.

56. Zuboff, S. (1988). In the age of the smart machine. New York: Basic Books.

Communication Theory, Vol. 16, No. 3 (August 2006): pg. 281-303. DOI. This article is @ Wiley and permission has been granted for this version to appear in e-Publications@Marquette. Wiley does not grant permission for this article to be further copied/distributed or hosted elsewhere without the express permission from Wiley. 
NOT THE PUBLISHED VERSION; this is the author's final, peer-reviewed manuscript. The published version may be accessed by following the link in the citation at the bottom of the page.

\section{Footnotes}

1 This right is often seen as the intent of elements within this document, such as the guarantee against illegal search and seizure, even though it is never spelled out. The Fourth Amendment to the U.S. Constitution holds that "[t]he right of the people to be secure in their persons, houses, papers, and effects from unreasonable searches and seizures, shall not be violated, and no warrants shall issue, but upon probable cause, supported by Oath or affirmation, and particularly describing the place to be searched, and the persons or things to be seized."

2 Though the two terms, monitoring and surveillance are often used interchangeably, and the distinction is often blurred when the purpose is unknown to the targets of EM/S, they are in fact wholly separate concepts. Monitoring is a much more benign term that can be applied to a variety of situations where data is collected for a number of reasonable or necessary reasons. Surveillance, however, often has a suspicious connotation associated with it because the collected information has the potential to impose negative consequences, such as curtailing certain behaviors of the target individual or individuals (Botan, 1996; Rule \& Brantley, 1992). Organizational members, however, may not be able to make this distinction when the monitoring or surveillance is conducted through electronic means. As a result, panoptic effects could result from either.

${ }^{3}$ Here, organizational culture is approached from an organizational cognition perspective (LeVine, 1984), where these elements (management style and communication climate) are shared concepts within the organization.

${ }^{4}$ While organizational policies could be considered an organizational factor; they are being treated as a separate component in the model because they are uniquely focused on the issue of monitoring and surveillance in the workplace.

${ }^{5}$ The ECPA of 1986 requires organizations to formally inform employees in advance of any potential surveillance. Any surveillance, without formal warning (e.g., formal policy, employee handbook, etc), has been found to be illegal by several courts.

Communication Theory, Vol. 16, No. 3 (August 2006): pg. 281-303. DOI. This article is @ Wiley and permission has been granted for this version to appear in e-Publications@Marquette. Wiley does not grant permission for this article to be further copied/distributed or hosted elsewhere without the express permission from Wiley. 
NOT THE PUBLISHED VERSION; this is the author's final, peer-reviewed manuscript. The published version may be accessed by following the link in the citation at the bottom of the page.

\section{Acknowledgment}

The author would like to thank Craig R. Scott who directed the dissertation upon which this article is based. Additionally, this manuscript could not have been completed without the assistance of John Cosgrove, Stephen A. Rains, Sarah Bonewits Feldner, Steven R. Goldzwig, and the anonymous reviewers for their feedback on earlier drafts of this article. 
NOT THE PUBLISHED VERSION; this is the author's final, peer-reviewed manuscript. The published version may be accessed by following the link in the citation at the bottom of the page.

Figure 1 Structural-Perceptual Model of Electronic Monitoring and Surveillance
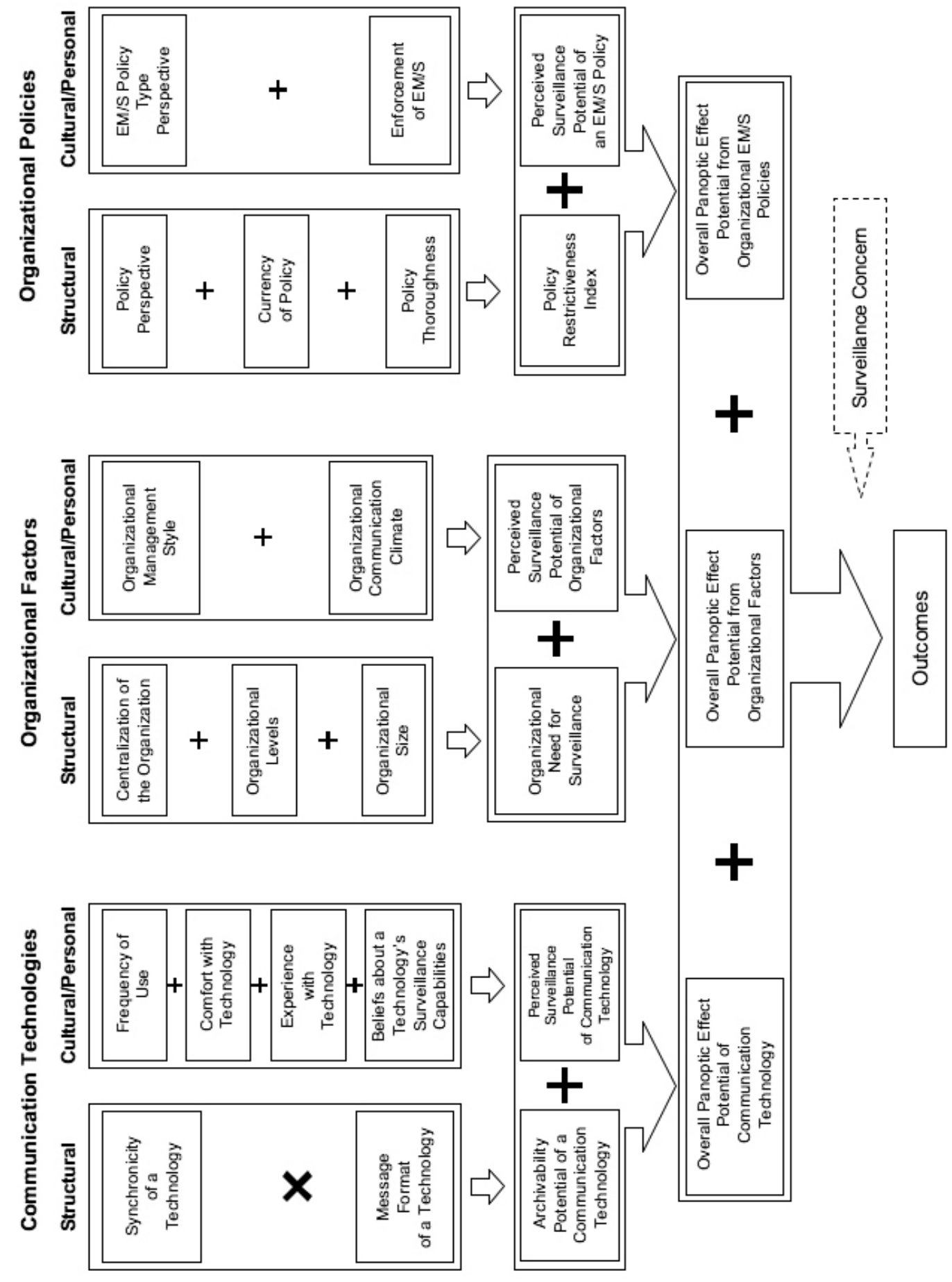

Communication Theory, Vol. 16, No. 3 (August 2006): pg. 281-303. DOI. This article is @ Wiley and permission has been granted for this version to appear in e-Publications@Marquette. Wiley does not grant permission for this article to be further copied/distributed or hosted elsewhere without the express permission from Wiley. 